\title{
QUALITY SOIL AND HEALTHY FOOD IN THE JEAN MONNET PROJECT
}

\section{KVALITA PÔDY A ZDRAVÉ POTRAVINY V PROJEKTOCH JEAN MONNET}

\author{
Zuzana Bohátová - Lucia Palšová - Norbert Floriš *
}

\section{Introduction}

Soil is one of the most important natural resources that provide us with vital goods and services to sustain life. It serves as a platform for human activities, landscape and heritage, and acts as a provider of raw materials ${ }^{(1)}$. Soil plays a central role in food safety as it determines the possible composition of food and feed at the root of the food chain ${ }^{(2)}$.

Numerous studies have shown that heavy metals in soil can accumulate in tissues, subsequently affect organ functions, and disrupt the reproductive, nervous or endocrine system. In general, heavy metal compounds are toxic, mutagenic, teratogenic, and carcinogenic in animals. They enter the body through ingestion, inhalation, or through the skin, and their presence can cause serious toxicity. Therefore, the health status in relation to xenobiotics should be monitored and explored. Soil contamination effected by the environmental pollution is one of the most pressing issues in the political and expertise debate on food safety within the related EU policies as Common agricultural policy, EU agri-environmental, EU food policy and EU health policy.

Food policy has to fulfil a range of objectives. It must provide

(1) European Commission, 2018

(2) Toth, G. at all, 2016

\section{Abstract (EN)}

Soil quality issues, together with issues related to healthy food, are becoming key areas of interest at the European level. Both spheres play an important role in the formulation of EU policies such as the EU Common Agricultural Policy, EU Agri-environmental Policy, EU Food Policy but also EU Health Policy. For this reason, deepening knowledge and exchanging experiences in these areas seem to be necessary preconditions for finding ways to respond to current challenges and problems. The project "Quality Soil as a Pathway to Healthy Food in the EU", acronym FOODIE, also reacts on the mentioned issues. The main aim of the project is to foster an expertise dialogue between the crucial experts (academics, public authorities, professionals from practice) in the field of food/feed management in the EU affecting the achieving the objectives of correlated EU policies and recently adopted European Green Deal.

The presented paper is of a disseminating nature and aims to acquaint the reader with the mentioned project.

\section{Keywords (EN)}

soil, healthy food, Jean Monnet projects food of good nutritional quality and promote diets that support good health. It has to achieve food security, it must be environmentally sustainable, it should ensure that animals are farmed to high welfare standards. Food policy needs to take an integrated approach, ensuring that one objective is not achieved at the expense of another.

For the period 2021 - 27, the European Commission proposes that the Common Agricultural policy (CAP) will be built around nine key objectives.

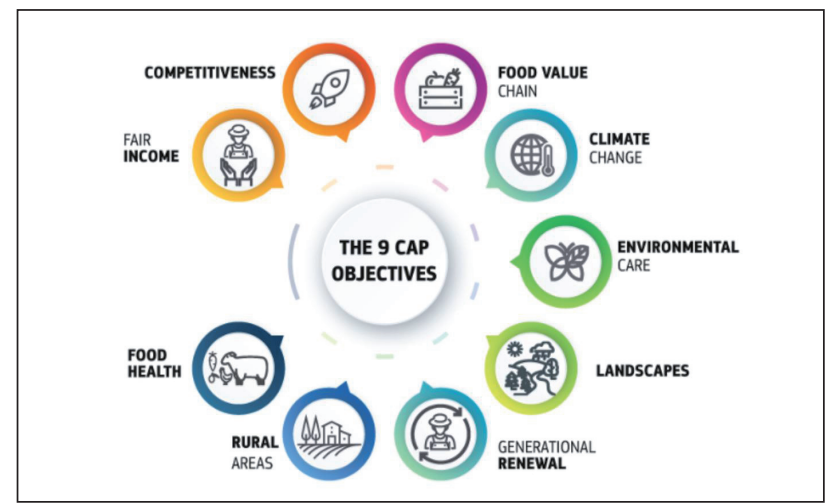

Source: European Commission: Key policy objectives of the future CAP

\section{Abstrakt (SK)}

Problematika kvality pôdy spolu s otázkami ohladne zdravých potravín sa v súčasnosti stávajú klúčovými sférami záujmu na európskej úrovni. Obe oblasti majú dôležité postavenie pri formulácii politík ako napr. Spoločná polnohospodárska politika EÚ, agro-environmentálna politika EÚ, potravinová politika EÚ ale aj politika zdravia EÚ. Z tohto dôvodu sa prehlbovanie poznatkov a výmena skúseností v týchto sférach zdá byt' nevyhnutným predpokladom pri hladaní spôsobov ako reagovat' na súčasné výzvy a problémy. Na spomínanú problematiku reaguje aj projekt "Quality Soil as a Pathway to Healthy Food in the EU", akronym FOODIE, ktorého hlavným cielom je podporit' odborný dialóg medzi relevantnými odborníkmi (akademikmi, verejnými orgánmi, odborníkmi z praxe) v oblasti manažmentu potravín/krmív v EÚ, ktorý prispeje $\mathrm{k}$ dosahovaniu cielov súvisiacich politík EÚ a nedávno prijatej Európskej zelenej dohody. Predkladaný článok je diseminačného charakteru a kladie si za ciel oboznámit' čitatela so spomínaným projektom.

\section{Klúčové slová (SK)}

pôda, zdravé potraviny, projekty Jean Monnet

Slovak University of Agriculture in Nitra, Slovakia 
Also, the Institute for European Environmental Policy ${ }^{(3)}$ defined five recommendations for shaping Europe's research mission on Soil Health and Food to achieve healthy and sustainable soils:

1. define a clear policy objective related to the major challenge of climate and environment,

2. develop concrete solutions to address hotspot issues in Europe,

3. effectively engage stakeholders and the public,

4. open international cooperation,

5. explore the soil microbiome.

European and international environmental documents strongly encourage EU Member States to set up actions to maintenance and protect food and feed (ESFA) based on the environmental justice and sustainable principles. Adopted EU documents: "The New Consensus on Development, Our World Our Dignity, Our Future", and "European Green Deal" have a political and legal potential for possible changes in the field. The realization of the possible legal measures in order to protect agricultural land requires in some cases to eliminate several obstacles, especially the constitutional obstacles caused by the rigid protection of the ownership right, the international legal obstacles caused by the law of European Union and the absence of any general strategies ${ }^{(4)}$.

\section{Project Description}

As a response to recommendations of the European Commission, Institute for European Environmental Policy and other authorities, the Faculty of European Studies and Regional Development and the Faculty of Biotechnology and Food Sciences of the Slovak University of Agriculture in Nitra prepared and submitted a common project "Quality Soil as a Pathway to Healthy Food in the EU", acronym FOODIE. The project was submitted under the Erasmus+ Jean Monnet program and it was approved in summer 2020, decision number 621119 , project number 621119-EPP-1-2020-1-SK-EPPJMO-PROJECT. Project activities started in September 2020 and they will finish in August 2021.

The project arises from the need to contribute to food safety, quality control and/or effects of risk factors of food chain on animal and human health status. Therefore, the main aim of the project is to foster an expertise dialogue between the crucial experts (academics, public authorities, professionals from practice) in the field of food/feed management in the EU affecting the achieving the objectives of correlated EU policies and recently adopted European Green Deal.

Specific objectives of the project are:

- to promote discussion about sustainability of the food quality a safety in the EU;

- to boost knowledge about the risk factors affecting soil contamination and food quality;

- to discuss and propose effective actions to enable sustainable agriculture and food safety in the EU.

\footnotetext{
(3) Hiller, Hulot, Kollenda, 2019

(4) Illáš, 2020
}

The main objective will be achieved through following activities:

- expertise discussing of experts at different levels of competences in the field of food/feed management;

- encouraging the professional cooperation between experts within the field;

- gathering and exchanging the knowledge and expertise among involved experts;

- providing information about the food/feed quality, risk factors of food chain and risk assessment to all target groups.

Cross-fertilization and spread content idea of the project is evident in the content of the proposed activities, while respecting multidisciplinary approach (political, legal, socio-economic, agro-technical and medical) to the issues addressed. Discussion about the EU risk factors of food chain will be led in mutual synergy of experts at different levels of competence (academics, public authorities, and professionals from practice) what may contribute to the further actions within the environmental, food and health policies.

In the frame of the project a webpage has been created (www. foodie.uniag.sk). This webpage contains all relevant information about the project, its activities and news from EU Policies. Staff involved in the project will prepare with collaborating institutions from the Netherlands, Germany, Italy, Czech Republic, Poland, Hungary, Bulgaria and Croatia a video presentation about Risk Factors Affecting Animal and Human Health in each of above-mentioned countries. These institutions will also cooperate on the report "Risk Factors of Food Chain in the EU - Perspectives" and researchers from involved countries will meet and present result of their research at an international scientific conference organized within the frame of this project. As a result, a conference proceeding will be published and new innovative approaches will be discussed and recommended by conference participants to local, regional, national and EU authorities.

Outcomes of the project will be:

- reinforced mutual cooperation among experts within the field;

- improved state-of-the-art knowledge in the field that will be used in teaching and further research and/or project activities of educational and research institutions in the EU;

- enhanced governance of food/feed production in the EU member states and subsequently in the EU;

- enforced EU and national policies and legislation correlated to the field (agriculture, environment, food and health).

Expected impacts of the project are: sustaining the food quality and safety in the context of the correlated EU policies; contribution to development of assessment of risk factors of food chain aspects in the EU; harmonization of political tools and implementation measures related to risk factors of food chain in the EU and increasing awareness of the impact of risk factors of food chain (as well as processing risks) on the animal as well human health status. 


\section{References}

1. EUROPEAN COMMISSION. 2018. Key policy objectives of the future CAP. Available at: https://ec.europa.eu/info/food-farmingfisheries/key-policies/common-agricultural-policy/future-cap/ key-policy-objectives-future-cap_sk.

2. ILLÁŠ, M. 2019. Agricultural soil and agricultural land- problems and challenges from the view of legal regulation. In EU Agrarian Law, vol. VIII, DOI: https://doi.org/10.2478/eual-2019-0002.

3. TOTH, G.- HERMANN, M.- RAVINA DA SILVA, M.- MONTANARELL, L. 2016. CAP Specific Objective: Efficient soil management. In Environment International vol. 88, March 2016, 299309 p. DOI: 10.1016/j.envint.2015.12.017.

4. STEVENSON, P. 2014. A Sustainable Food Policy for Europe Towards a sustainable, nourishing and humane food policy for Europe and globally. Available at: https://www.ciwf.org.uk/ media/5858105/a-sustainable-food-policy-for-europe-executive-summary.pdf

5. HILLER, N.- HULOT, J.F.-KOLLENDA, E. 2019. Five recommendations for shaping Europe's research mission on Soil Health and
Food (Institute for European Environmental Policy). Available at: https://ieep.eu/news/five-recommendations-for-achievinghealthy-soils-by-2030-through-horizon-europe.

6. Quality Soil as a Pathway to Healthy Food in the EU (FOODIE): Project description, Selection 2020 - Call for proposals EAC/

\section{Contact address/ Kontaktná adresa}

\section{Ing. Zuzana Bohátová, PhD.}

Centre of International Programmes, FESRD,

SUA in Nitra, Tr. A. Hlinku 2, 949 76, Nitra,

e-mail: zuzana.bohatova@uniag.sk

Doc. JUDr. Lucia Palšová, PhD.

Department of Law, FESRD,

SUA in Nitra, Tr. A. Hlinku 2, 949 76, Nitra,

e-mail: lucia.palsova@uniag.sk

\section{Ing. Norbert Floriš}

Centre of International Programmes, FESRD,

SUA in Nitra, Tr. A. Hlinku 2, 949 76, Nitra,

e-mail: norbert.floris@uniag.sk

With the support of the Erasmus+ Programme of the European Union
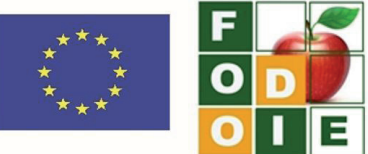